\title{
Transient Receptor Potential Cation Channel Subfamily M Member 7
}

National Cancer Institute

\section{Source}

National Cancer Institute. Transient Receptor Potential Cation Channel Subfamily M

Member 7. NCl Thesaurus. Code C98060.

Transient receptor potential cation channel subfamily M member 7 (1865 aa, 213 kDa)

is encoded by the human TRPM7 gene. This protein plays a role in the modulation of both divalent cation transport and serine/threonine phosphorylation. 